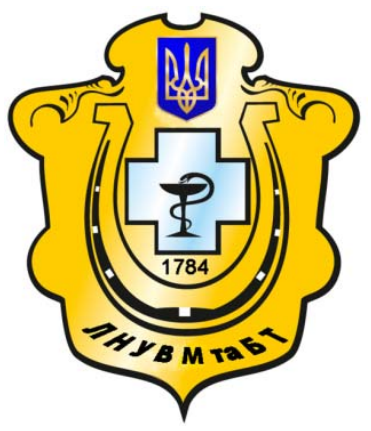

Науковий вісник Львівського національного університету ветеринарної медицини та біотехнологій імені С.3. Гжицького

Scientific Messenger of Lviv National University of Veterinary Medicine and Biotechnologies named after S.Z. Gzhytskyj

doi:10.15421/nvlvet7008

ISSN 2413-5550 print

ISSN $2518-1327$ online

$\underline{\text { http://nvlvet.com.ua/ }}$

УДК 619:616.98:636.8

\title{
Макроскопічні зміни при проліферативній ентеропатії свиней
}

\author{
С.Є. Гаркуша, Я.О. Продоляк \\ stas_grin@mail.ru
}

Національний університет біоресурсів і природокористування Украӥни, вул. Героїв Оборони, 15, м. Київ, 03041, Украӥна

\begin{abstract}
Дослідники проліферативну енетропатію свиней відносять до маловивчених хвороб. Лише останнім часом вчені з'ясували, що в свинарських господарствах інфекиія має тенденцію до широкого розповсюдження. У нашій державі проліферативна ентеропатія свиней майже не вивчалася. Тому метою даної роботи було більш детально вивчити макроскопічні зміни при проліферативній ентеропатії свиней.

Для досягнення даної мети були поставлені наступні задання: провести патолого-анатомічний розтин свиней шо загинули від проліферативної ентеропатії, вивчити макроскопічні зміни у внутрішніх органах за даної хвороби, та детально описати макроскопічні зміни у тих внутрішніх органах, щзо раніше не описувались.

Матеріалом для дослідження слугували 10 трупів свиней, щчо загинули від проліферативної енетропатії. Патологоанатомічний розтин проводили в спинному положенні методом часткової евісиерачії в загальноприйнятій послідовності на кафедрі патологічної анатомії Національного університету біоресурсів і природокористування України.

При патолого-анатомічному розтині макроскопічні зміни при проліферативній ентеропатії в свиней були такі: виразне потовщення стінки каудальної частини порожньої, клубової, сліпої й ободової кишок, щуо супроводжувалося виразним звуженням їх просвіту. Реєстрували геморагічне запалення лімфовузлів тонкої, сліпої й ободової кишок. В легенях венозний застій та їх набряк, а також дилатачію серия $і$ застійну гіперемію печінки.

Ключові слова: патолого-анатомічний розтин, макроскопічні зміни, свині, легені, серче, нирки, лімфатичні вузли, проліферативна енетропатія, Lawsonia intracellularis.
\end{abstract}

\section{Макроскопические изменения при пролиферативной энтеропатии свиней}

\author{
С.Е. Гаркуша, Я.О. Продоляк \\ stas_grin@mail.ru \\ Национальный университет биоресурсов и природопользования Украины, \\ ул. Героев Обороны, 15, г. Киев, 03041, Украина
}

Исследователи пролиферативную энетропатию свиней относят к малоизученным болезней. Лишь в последнее время ученые выяснили, что в свиноводческих хозяйствах инфекиия имеет тендениию к широкому распространению. В нашем государстве пролиферативная энтеропатия свиней почти не изучалась. Поэтому целью данной работы было более детально изучить макроскопические изменения при пролиферативной энтеропатии свиней.

Для достижения данной цели были поставлены следующие задачи: провести патологоанатомическое вскрытие свиней погибших от пролиферативной энтеропатии, изучить макроскопические изменения во внутренних органах у данной болезни, и подробно описать макроскопические изменения в тех внутренних органах, в которых они ранее не описывались.

Материалом для исследования служсили 10 трупов свиней, погибщих от пролиферативной энетропатии. Патологоанатомическое вскрытие проводили в спинном положении методом частичной эвисиерации в общепринятой последовательности на кафедре патологической анатомии Национального университета биоресурсов и природопользования Украины.

При патологоанатомическом вскрытии макроскопические изменения при пролиферативной энтеропатии у свиней были следующие: утолщение стенки каудальной части тощей, подвздошной, слепой и ободочной кишок, что сопровождалось отчетли-

\section{Citation:}

Garkush, S.E., Prodoljak, J.O. (2016). Macroscopic changes in proliferative enteropathy of pigs. Scientific Messenger LNUVMBT named after S.Z. Gzhytskyj, 18, 3(70), 33-35. 
вым сужением их просвета. Регистрировали геморрагическое воспаление лимфоузлов тонкой, слепой и ободочной кишок. В легких венозный застой и их отек, а также дилатацию сердияа и застойную гиперемию печени.

Ключевые слова: патологоанатомическое вскрытие, макроскопические изменения, свиньи, легкие, сердие, почки, лимфатические узль, пролиферативная энетропатия, Lawsonia intracellularis.

\title{
Macroscopic changes in proliferative enteropathy of pigs
}

\author{
S.E. Garkush, J.O.Prodoljak \\ stas_grin@mail.ru \\ National university of life and environmental sciences of Ukraine, \\ Heroyiv Oborony Str., 11, Kyiv, 03041, Ukraine
}

Infectious diseases cause significant economic damage to the industry and one such disease is proliferative enteropathy.

So scientists have estimated that, for example, in Australia, the losses amount to dollars 20 per 1 pig, and in the United States losses from proliferative enteropathy in pigs was dollars 20 million annually.

Symptoms and signs of the disease are known to scientists for a long time. But only in 1974, scientists discovered a bacterium that multiplies rapidly abnormally in the cells, it has been called Lawsonia intracellularis. And it is proved that it is the causative agent of the disease, in 1993.

Recently we discovered that the infection in pig farms tend to widespread. According to the results of serological tests in different countries of Lawsonia intracellularis it is $60-90 \%$ of the herd of swine. Other authors have reported that around the world are infected with this microorganism is from $30 \%$ to $100 \%$ of herds of pigs. Serological studies have established that Lawsonia intracellularis in the United States recorded in $96 \%$ of the herd of swine. This is facilitated by the low infectious dose of pathogen isolation from faeces of a large number of bacteria, sustained release of the pathogen in the faeces and survival of Lawsonia Intracellularis in the environment for at least 2 weeks.

In our state proliferative enteropathy pigs hardly been studied. In Ukraine, proliferative enteropathy pigs was detected in 15 pig farms 7 areas. In Russia, the disease is called a new and poorly understood, but some scientists call it lavsoniosis.

Therefore the aim of this study was to examine in more detail the macroscopic changes at proliferative enteropathy pigs.

To achieve this goal the following objectives: to conduct mortem examination of dead pigs of proliferative enteropathy, examine macroscopic changes in the internal organs of the disease, and a detailed description of the macroscopic changes in the internal organs, which they were not previously documented.

The material for the study were 10 corpses of pigs killed by proliferative enteropathy. Mortem examination was carried out in spinal position by partial evisceration in a common sequence at the Department of Pathological Anatomy of the National University of Life and Environmental Sciences of Ukraine.

At postmortem macroscopic changes at autopsy proliferative enteropathy in pigs were the following: thickening of the walls of the caudal part of the jejunum, ileum, cecum and colon intestine, which was accompanied by a distinct narrowing of the lumen. Swollen lymph nodes were recorded hemorrhagic thin, blind and colon. In mild venous congestion and edema and dilation of the heart and congestive hyperemia of the liver.

Key words: mortem autopsy, macroscopic changes, pigs, lungs, heart, kidneys, lymph nodes, Proliferative Enetropathy, Lawsonia intracellularis.

\section{Вступ}

Свинарство в Україні має глибокі історичні традиції та одна $з$ провідних галузей сільського господарства і вважається прибутковим бізнесом.

Інфекційні хвороби завдають значних економічних збитків галузі і однією з таких хвороб є проліферативна енетропатія (Nychyk et al., 2014). Симптоми та ознаки даного захворювання відомі вченим ще 330 років минулого століття. Але лише в 1974 році вчені відкрили бактерію, що аномально швидко розмножується в клітинах, іiі було названо Lawsonia intracellularis. А доведено, що саме вона є збудником цієї хвороби, лише в 1993 р. В даний час відомо, що проліферативною ентеропатією уражено 96\% всіх свинарських ферм і 30\% всього свинопоголів'я на дорощуванні і відгодівлі в світі. В Україні проліферативну ентеропатію свиней було виявлено в 15 свинарських господарствах 7 областей (Ajshpur et al., 2013; Nychyk et al., 2014; Potoc'kyj, 2008).

Метою роботи було більш детально вивчити макроскопічні зміни при проліферативній ентеропатії свиней.
Для досягнення даної мети були поставлені наступні задання: провести патолого-анатомічний розтин свиней шо загинули від проліферативної ентеропатії, вивчити макроскопічні зміни у внутрішніх органах за даної хвороби, та детально описати макроскопічні зміни у тих внутрішніх органах, що раніше не описувались.

\section{Матеріал і методи досліджень}

Матеріалом для дослідження слугували 10 трупів свиней, що загинули від проліферативної енетропатії. Патолого-анатомічний розтин проводили в спинному положенні методом часткової евісцерації в загальноприйнятій послідовності (Goral's'kyj et al., 2005; Zon et al., 2009) на кафедрі патологічної анатомії Національного університету біоресурсів і природокористування України.

\section{Результати та їх обговорення}

При патолого-анатомічному розтині трупів основні макроскопічні зміни нами було знайдено в кауда- 
льній частині порожньої кишки, а також у клубовій та ободовій кишках.

Стінка каудальної частини порожньої, а також клубової кишки була виразно потовщена, а її слизова оболонка утворювала товсті складки. Внаслідок цього ззовні (з боку серозної оболонки) кишка мала вигляд, подібний до закруток великих півкуль головного мозку.

Стінка сліпої й ободової кишок також виразно потовщувалась, а ії слизова оболонка утворювала товсті складки, внаслідок чого ззовні вона часто ставала схожою на товстостінний гофрований шланг.

Внаслідок потовщення стінок каудальної частини порожньої кишки, а також клубової, сліпої й ободової кишок їх просвіт виразно звужувався.

Лімфовузли тонкої, сліпої й ободової кишок були виразно збільшені, темно-рожевого чи темночервоного кольору. Брижа тонкої, сліпої й ободової кишок в 9 тварин була гіперемійована.

У 6 тварин при дослідженні серця спостерігали дилатацію його правої половини, що характеризувалася зміною співвідношення товщини міокарда правої половини до лівої, як 1:5 і більше. Серцевий м'яз на розтині мав сіро-червоний колір. Кровоносні судини серця були виразно розширені, переповнені кров'ю. В усіх камерах серця знаходили темно-червону згорнуту кров.

Легені при макроскопічному дослідженні у 7 поросят збільшені, важчі від звичайних, вишневочервоного кольору, тістуваті при пальпації, їх шматочки важко плавали у воді. 3 поверхні розрізу стікала червонувата піниста рідина. Бронхи і трахея були заповнені такою ж пінистою рідиною.

При дослідженні печінки у 6 поросят вона була збільшена в об'ємі, щільної консистенції, капсула напружена, гладка, передній край був заокруглений. На розрізі тканина печінки строката через чергування дрібних вогнищ червоного, темно-червоного і жовтого кольору. Кровоносні судини печінки розширені, повнокровні.

Нирки з поверхні мали темно-червоний колір. Такий же колір на розрізі мали як їх кіркова, так і моз- кова речовини. При цьому межа між кірковою й мозковою речовинами була досить чіткою.

Також слід відзначити, що макроскопічно помітні зміни в шлунку, дванадцятипалій, початковій і середній частинах порожньої, в прямій кишці, селезінці та лімфовузлах грудної порожнини нами в жодному 3 випадків знайдені не були.

\section{Висновки}

При патолого-анатомічному розтині макроскопічні зміни при проліферативній ентеропатії в свиней були такі: виразне потовщення стінки каудальної частини порожньої, клубової, сліпої й ободової кишок, що супроводжувалося виразним звуженням їх просвіту. Реєстрували геморагічне запалення лімфовузлів тонкої, сліпої й ободової кишок. В легенях венозний застій та їх набряк, а також дилатацію серця і застійну гіперемію печінки.

Перспективи подальших досліджень. Провести гістологічні дослідження внутрішніх органів свиней що загинули від проліферативної ентеропатії.

\section{Бібліографічні посилання}

Ajshpur, O.Je. Sapon, N.V., Omeljanenko, M.M. (2013). Patomorfologichni zminy pry proliferatyvnij enteropatii' svynej. Veterynarna medycyna. 97, 279281 (in Ukrainian).

Goral's'kyj, L.P., Homych, V.T., Konons'kyj, O.I. (2005). Osnovy gistologichnoi' tehniky i morfofunkcional'ni metody doslidzhennja u normi ta pry patologii'. Zh.: «Polissja» (in Ukrainian).

Zon, G.A., Skrypka, M.V., Ivanovs'ka, L.B. (2009). Patologoanatomichnyj roztyn tvaryn: Navchal'nyj posibnyk. Donec'k, PP Glazunov R.O. (in Ukrainian).

Nychyk, S.A. Ajshpur, O.Je., Sapon, N.V. (2014). Proliferatyvna enteropatija svynej u svynars'kyh gospodarstvah Ukrai'ny. Visnyk agrarnoi' nauky. 9, 65-68 (in Ukrainian).

Potoc'kyj, M. (2008). Proliferatyvna enteropatija svynej. Veterynarna medycyna Ukrai'ny. 4, 24-26 (in Ukrainian).

Стаття надійшла до редакиії 16.09.2016 